\title{
KOOPTACE PROTESTU, EKOLOGICKÁ KRIZE A DILEMA „EKOLOGICKÉ MODERNIZACE“
}

\author{
OLEG SUŠA
}

\section{Úvod}

Dynamika života moderních společností s sebou nese vedle zájmových konfliktů také stálé napětí mezi demokratickou participací a úsilím o sociální přeměny na jedné straně - a snahami o jejich institucionální integraci a mocenskou kooptaci na straně druhé.

$\mathrm{V}$ tomto příspěvku se pokusíme poukázat na určitou tendenci k systémové kooptaci kultury ekologické výzvy a protestu proti rizikům a ohrožením života na Zemi. Pojem kooptace možno obecněji vymezit jako začlenění a integraci elementů protestu či kritiky do nějaké stávající nebo utvářející se sociální struktury, ideologie či institucionálního uspořádání. Jedním z efektů takové integrace je využití elementů inovace pro opětovnou legitimizaci moci nebo pro nové cesty udržení funkčnosti systému jeho funkční adaptací (např. ve smyslu inovačního přizpůsobení se proměnám prostředí). Dané téma lze indikovat a interpretovat ve třech rovinách:

Za prvé, podporuje-li kooptace udržení statu quo, pak možno začleňování hnutí či idejí do systému moci (politické, ekonomické či kulturně-ideové) interpretovat bud' kladně - ve smyslu kupř́íkladu udržení nebo prohloubení demokratické povahy systému (např. fungování politického systému) či dokonce ve smyslu systémové kvalitativní změny - anebo negativně, ve smyslu zneužití symbolů či inovací, s nimiž vystoupila hnutí při své kritice společenských poměrů k legitimizaci konzervování stávající moci, její struktury a reprodukce - aniž by ovšem docházelo k podstatnějším (tedy více než jen kosmetickým) strukturálním a systémovým změnám stávajících poměrů. V negativním významu je tedy kooptace jevem spíše nepř́iznivým demokracii a jejímu rozkvětu, kdežto v pozitivním může kooptace způsobit určité, relativní, postupné změny stávajících poměrů, přinést inovace a napomoci další demokratizaci či prohloubení demokracie.

Za druhé, kooptace a absorbování do systému, aniž by se změnil systém sám: umožňuje hlavně systému další přežití - to, co se mění, je způsob legitimizace moci elit, nebo mocenských oligarchií anebo výkonu moci byrokratických aparatur atd. Kooptace způsobí dezintegraci, rozdrobení, oslabení radikálnosti (jako hrozby systému a udržování moci) nebo degeneraci a zánik původního hnutí. Kooptace může způsobit také přeložení cílů - kdy jsou původní cíle subjektu či aktéra, jenž je nebo byl kooptován - rozmělněny a nahrazeny jinými, cizími cíli (v rafinovanější podobě jsou naroubovány v průběhu aktu převlékání kabátů, nasazování masek, pragmatického využívání rétoriky s repertoárem vypůjčených pojmů, hesel). Původní strategické cíle hnutí mohou být také prostě nahrazeny prostředky - např. snahou udržet především moc a vliv hnutí samotného v novém kontextu (kupříkladu byrokraticko-organizačním). 
Za třetí, pokud kooptace a integrace do systému prosakuje mnoha póry společenského systému může komunikačně ovlivnit systém tak hluboce, že dojde k systémové (strukturální nebo hodnotové orientační) změně. Paralelně se změnami systému probíhá proces transformace samotného hnutí - hnutí ztrácí výhody překvapení a novosti přitahující pozornost občanské veřejnosti nebo pozornosti hlavních institucí, nebo ztrácí na síle a vli$\mathrm{vu}$, anebo konečně se jeho aktéŕi identifikujís měnícím se - to znamená s „novým “ modifikovaným systémem a podle toho jednají nikoli směrem $\mathrm{k}$ destrukci systému nebo k jeho zásadní „systémové“ či radikální hluboké rekonstrukci, ale spíše začnou tendovat k jeho reprodukci a zachování. Kooptace může mít podobu „rutinizace charismatu“ původní prorocké výzvy - tj. z proroků kritiky upozorňujících na nová témata a problémy statu quo se stávají „,kněži“ - a spolu s tím se mění nejen struktura rolí a statusu (včetně mocenské pozice), ale mění se i obsah, smysl původních cílových myšlenek sociálního hnutí.

Transformace systému a paralelní proměna iniciátorů změny, „,inovátorư“ $\mathrm{z}$ vnějších a „nezávislých svobodných" kritiků ve vnitřní reformátorské reprezentanty, v členy organizovaných institucí svazované spoluodpovědností atd. - mohou být pozorovány jako jeden vzájemně propojený proces. $\mathrm{V}$ jeho průběhu může nastat proměna aktérů-nositelů změny $\mathrm{z}$ více či méně radikálních ve více či méně konzervativní (na paměti máme relativnost podmíněnou vztahovými kritérii, hledisky a pozicemi, z nichž jsou tito aktéri hodnoceni).

Významnou roli hraje dynamika a nestálost, poprrípadě turbulentnost kontextů, v nichž tento proces kooptace / rutinizace charismatu probíhá.

$\mathrm{V}$ dynamickém prostředí velké soutěže a rychlé inovace dochází také $\mathrm{k}$ rychlému zastarávání inovací: v tomto smyslu mohou zastarávat též ideje a cíle občanských iniciativ a sociálních hnutí: např̀ z hlediska nedokončenosti nebo neúplnosti uskutečňování cílů a změn. Je třeba také diferencovat podle rozsahu a komplexnosti prostředí - v lokálním, makrospolečenském či globálním, nebo v kontextu jedné instituce, či specifické oblasti společenské činnosti apod.

Specifickým problémem je neorganičnost nebo napětí mezi vyhlašovanými cíli (utopické nápravy ) a realit ve fungování a strukturaci systému, vezmeme-li v úvahu reálný fenomén rezistence systémových struktur, či jejich prvků anebo fenomén reakce v podobě odmítnutí cílů (sociálního hnutí) a kontra-akce. Rezistence a protiakce jiných aktérů (včetně tzv. anti-hnutí) komplikují a mění kontext jednání: subjekt, nositel ideálu změny musí čelit odporu a k tomu mobilizovat energii, hledat zdroje a spojence, kteří mají ješš své jiné, specifické zájmy. Přitom může být nucen k mnoha kompromisům, např́ílad ustupovat od původních cílů, revidovat je nebo modifikovat $\mathrm{v}$ souladu se změněným prostředím situačních kontextů. $\mathrm{V}$ této souvislosti sehrávají závažnou roli obavy z marginalizace hnutí - např́ílad pokud nevyužijí nabídky kooptace a zůstanou ve fundamentalistické opozici, dostanou se aktéŕi do izolace, hnutí ztratí podporu v širším prostoru (např. v mediální komunikaci), ztratí vliv v mocenském vyjednávání apod.

\section{Nová sociální hnutí, krize legitimity institucí a rozšírení platformy politiky}

Sociální hnutí jsou považována za významný projev kolektivního chování, za vlivnou sílu utváření a změny společností, popřípadě za kolektivní aktéry [Touraine 1981], kteří 
působí na sociálně-historické struktury v rámci určitých širších podmínek spojených s jejich historickou konfigurací. Podle A. Touraina jsou lidské společnosti vytvářeny opozičními, navzájem zápasícími sociálními hnutími, jejich zápas je bojem o „kontrolu dějinnosti“ - tento zápas lze považovat zároveň za reflexivní jednání. V tomto smyslu jde o proces vytváření společnosti jako výsledek vědomé reflexe jednání, která působí na jednání i jeho podmínky. Podle Touraina jde v moderní společnosti o konflikt „dominantní třídy“, která si přivlastnila historicitu s „třídou ovládanou“, jež usiluje o totéž. Vládnoucí vytváří sociální řád a usiluje o udržení jeho statu quo, konkurující třída identifikuje rozpory stávajícího řádu a usiluje o jeho inovace a změny. Sociologické přístupy dnes diferencují mezi sociálními hnutími „starými a novými“, přitom hlavní rozdíl vidí v důrazu na definici hlavního či ústředního konfliktu ve společnosti - bud' kolem otázek ekonomických rozporů kontroly systému produkce, nebo okolo otázek způsobu myšlení, životního stylu, kulturních hodnot.

Soudobé pozdně moderní společnosti, jak se zdá jejich analytikům, produkují konflikty stále více kulturně-symbolické povahy, kontrola historicity kolektivních aktérů má podobu kontroly informací a vědění, jde o spory např́iklad mezi technokratickými systémovými principy seberegulace institucí a organizačních struktur a autonomií života lidí a jejich seberozvoje. Politika přesahuje své omezení v rámci politické organizace formálního politického systému, proniká všemi sférami sociálního života a ruší fakticky staré oddělení, či protikladnost mezí veřejným a soukromým. Ve všech sférách sociálního života jde proto o otázky moci, její kontroly a legitimity: spory o kulturní orientace jednání procházejí všemi sférami, konflikty a artikulace politických problémů mohou, ale nemusí být plně rozvinuty v oblasti institucí politického systému (stát, parlament, politické strany, volby). V komplexních společnostech narůstá širší spektrum alternativních kulturně-politických prostorů komunikace, voleb, rozhodování - jež se vzájemně prostupují a ovlivňují. Nová občanská hnutí protestu proti hrozbám životního prostředí (environmentalistická hnutí) například vznikala jako platforma suplující vakuum v institucionální strukturaci moderní průmyslové společnosti okolo rostoucí výbušnosti politické povahy tzv. vedlejších di̊sledků ekonomicko-technologického rozvoje a růstu. Tyto vedlejší důsledky systému produkce a reprodukce hlavních institucionálních sfér společenského jednání nahromadily konflikty nikoli kolem distribuce zisků a výhod či společenského bohatství, nýbrž kolem distribuce rizik a ohrožení [Beck 1986, 2004].

Podle soudobých analýz jde o velmi rozsáhlý kulturní a politický problém řešení protikladných nárokủ či priorit $v$ životě moderních společností (zejména např. technickoekonomický růst, masová spotřeba i zdravé a harmonické životní prostředí). Přitom však růst celkové výkonnosti při produkování bohatství vytváří růst negativních důsledků v ekologické (resp. přesněji př́rodně-technologické) a sociální sféře životního prostředí, produkce negativních vedlejších důsledků zpochybňuje politické regulativní mechanismy a jejich efektivnost při jejich preventivní kontrole. Takto např. Beck hovoří o krizi legitimity systému společenské moderny průmyslové společnosti jako celku, vyplývající $\mathrm{z}$ nedostatečné politické účinnosti kontroly produkce společenských rizik: problémy způsobené průmyslovým, vědeckotechnickým rozvojem, trhem, konkurencí a inovací mají řešit parlamenty, politické strany a vlády národních států [Beck 1988]. Výsledek má podobu kontrastu mezi snahami o legitimizaci statu quo hlavních institucí (včetně 
normalizování rizik) a faktickým pokračováním kumulace negativních důsledků jejich fungování. Ekologická krize je součástí hluboké krize institucionální.

Další rovinou problematiky soudobých sociálních hnutí je související otázka pojetí kontextu kooptace, tj. politické sféry rozlišující klasické pojetí politiky, jako oblasti užšího politického systému, v němž se odehrává zápolení a soutěžení politických aktérů (politických stran, hnutí či asociací) o moc ve státě (jako centrální politické instituci umožňující proces politického vládnutí nad celkem národní společnosti, tj. jako centra moderní společnosti) a pojetí širší politické sféry diferencované a pluralizované v rámci různých oblastí společenského života [Nash 2000: 77-78].

V rozšířeném pojetí politického procesu se jedná o širší politické pole, překračující nejen sféru institucionální politiky, ale také hranice národních státư, a tím také jednotlivé společnosti v soudobém globalizovaném světě. Nadnárodní, transnacionální prostory v pokračující globalizaci otevírají novou otázku, zda nejen instituce a organizace, ale i sociální hnutí nejsou stále ještě spíše omezena na bezprostřední kontexty národně státních společností - a tudiž nejsou dostatečně účinná v globálním kontextu. Vzniká např. otázka, zda relativní slabost nadnárodních nevládních organizací není způsobena ne/spoluprací s institucemi globální povahy, vyplývající bud' z jejich slabosti či z jejich neexistence: neexistuje ani globální společnost, ani globální vláda, existují zatím pouze instituce typu mezinárodních organizací (OSN aj.), které jsou ovšem tak či onak generovány kontextem zájmů a vztahů jednotlivých národních států, sledujících především vlastní, nikoli globální zájmy.

Tourainova teorie sociálních hnutí zdůraznila pokles významu instituce státu v transformacích komplexních moderních společností, s tím, že sociální hnutí působí svým jednáním na sociální změnu $\mathrm{v}$ různých sférách společenského života a nikoli pomocí státu. Touraine se dotkl otázky kooptace sociálních hnutí pouze v rámci tradičního schématu politiky v užším smyslu (v rámci politického systému). Jakmile sociální hnutí vstoupí na platformu politického systému, je kooptováno do stávajícího řádu a dostává se do rozporu s radikální změnou, o níž usiluje. Podobně - nikoli však zcela poukazuje I. Wallerstein na otázku kooptace jako na historickou zkušenost spojenou s dělnickým hnutím sociální demokracie. Podle Wallersteina vznikla nová hnutí „rezistence proti systému“ kolem roku 1968 především díky nespokojenosti s kooptováním dělnických a socialistických hnutí do politického systému. Po získání politické moci ve státě, začala tato „stará“ hnutí udržovat status quo a zradila myšlenky revoluční změny. To podle Wallersteina rovněž působilo na rostoucí nezájem o význam státu, či „odvrat od státu“ a od podpory reformních změn. Skepse vůči státu a úpadek jeho legitimity jsou doprovázeny také růstem nejistot a násilí v soudobém světě [Wallerstein 2000: 262-263].

Podobné závěry Touraina a Wallersteina dokládají význam přesunu váhy od úzkého pojetí politiky směrem k širšímu pojetí, nezabývají se však otázkou nových či alternativních možností a důsledků kooptování nových sociálních hnutí právě v širším poli politického vývoje komplexních společností, v rámci širších kontextů a institucí, než je sféra politické soutěže o moc ve státě. $V$ tomto smyslu se pokusíme o nástin problému kooptace na případu procesu inkorporace, začlenění a integrace environmentalismu v soudobých souvislostech globalizace. Klíčovým pojmem zde bude „ekologická modernizace“ jako široký, pluralizovaný, často protikladný proces. 


\section{Rutinizace ekologického proroctví}

Ideu kooptace se nyní pokusíme aplikovat na současné procesy integrace protestu a diskuse o ekologické krizi a politice životního prostředí v podobě tzv. ekologické modernizace. Domnívám se, že i v této širší kulturní sfére je možné využívat Weberovy myšlenky o „rutinizaci charismatu“, Paretovo pojetí kooptace jako doplňování mocenské elity, či Bourdieuovský koncept mandarínství.

Životní prostředí bylo poměrně dlouho chápáno jako fyzické okolí člověka a jeho sociálního světa, jako mimolidské prostředí v kontrastu s kulturním, vytvořeným sociálním prostředím. Takové pojetí životního prostředí je dnes již překonáno a mluví se o „přírodě uvnitř společnosti a civilizace" a o tom, že problematika životního prostředí je sociální problém. Ekologický diskurz průmyslové civilizace je tedy diskurzem nikoli pouze o životním prostředí, o prrírodě - ale je třeba také vidět, jaké sociální cíle a projekty vznikají $a$ jsou vytvářeny v souvislosti s problematikou ochrany a péče $o$ životní prostředí, ve jménu „ekologizace“ či „zelenáni“ společnosti, ekonomiky i politiky. Diskurzy ekologického hnutí se týkají celé řady oblastí života moderní společnosti a vytvářejí totalizující utopie nápravy světa, utopie „o ekologické společnosti“ jakožto „utopie jiného typu univerzalizující kritické vize“ [Alexander 2001: 583].

V mnoha projevech a projektech environmentálního diskurzu můžeme najít radikální kritiku průmyslové společnosti. Tzv. environmentalistická hnutí je přesněji možno definovat jako koalice různých tendencí - např́klad morálně či esteticky motivovaných, vědecky odborných (např. bio-vědy) a technicistně manažerských (řízení a správa využití zdrojů a surovin). Tyto koalice nejsou nutně založeny na stejných sdílených zájmech, ale spiše na společných, sdílených pojmech - odtud se někdy mluví o tzv. diskurzivních koalicích. Ekologické kritiky soustředěné na prokazování dopadů a důsledků industrialismu na př́rodu chápanou jako nevinnou a čistou (morální odsudek nemravné společnosti, která nevidí nezamýšlené důsledky své činnosti), vyvolaly v různých kontextech sociální činnosti celý řetěz programů nových technologií a vědeckého managementu „konzervace př́rody“. Vyvstává otázka, zda ve skutečnosti industriální systém nevyužil ekologické kritiky ke svému zdokonalení na přibližně stejných základech a principech, díky nimž negativní ekologické důsledky vytvořil. Je možno analyzovat systémové změny - zejména v kulturních symbolických kódech, které ukazují na určité posuny v pojetí politického procesu, $\mathrm{v}$ jeho systémových principech a cílových či hodnotových orientacích. Odtud lze hovořit o sociální dynamice politiky (a teorie) životního prostředí jako o relativně dlouhodobém procesu, v němž probíhá napětí mezi fundamentální kritikou a snahou o systémovou sebepřeměnu na jedné straně a kooptací prvků reformní kritiky ke zdokonalování či opětovné legitimizaci systému na straně druhé.

Již M. Weber představil proces rutinizace charismatu jako konfliktní dialektický proces - inovace a rutinizace ve vzájemném napětí ( $\mathrm{v}$ dějinách náboženství šlo např̀. o tenze mezi dogmaty a heresí). Inovativní myšlenky a nové vědění v různém kontextu mění svůj smysl, původní revoluční či transcendentální sdělení ztratí či oslabí svůj obsah v kontextu svého př̀kladu do rutinizovaného jazyka byrokratizované procedury a technické institucionalizace, moc proroků přechází v moc kněží [Weber 2001: 183-189].

Evropská environmentalistická tradice protestu je spojena silně s romantismem a kulturní kritikou moderny - po Velké francouzské revoluci byla ovlivněna nostalgií konzer- 
vatismu a idealizací venkovské společnosti a kultury stavovské Gemeinschaft. Modernistická kultura industriální společnosti považovala dlouho tuto kulturní kritiku i s ochranou přírody a její čistoty za nepřátelskou silám nezadržitelného pokroku pod vedením vědy a techniky jako hlavním legitimizátorem ekonomického růstu zisků a redistribuce ekonomického bohatství.

Ve druhé polovině 20. století se vedle urbanistických a ochranářských tendencí objevila environmentalistická občanská hnutí či koalice protestu proti ohrožování přírodních předpokladů lidstva ideově vedená právě příslušníky vědecké obce - jako kulturní elity s velkou prestiží - myšlenky a pojmy ekologie jako vědy o komplexní vzájemné závislosti živých i neživých entit v pozemské př́rodě se staly symbolickým kódem nové „post-moderní“ environmentalistické kulturní kritiky či kontrakultury rozvíjené od 60. let. Paradoxně tak věda, jako instituce využívaná $\mathrm{k}$ aplikacím v technologiích růstu průmyslové civilizace a jejího bohatství i k legitimizaci celého systému státní hospodářské politiky rozvoje i politiky kapitalistických podniků - stála v čele ekologické kritiky tohoto systému. Proces modernizace narazil na vlastní úspěchy, industriální společnost přerostla ve společnost rizikovou [Beck 1986, 2004], v níž ústředním sociálním konfliktem není pouze redistribuce zisků a blahobytu, ale také distribuce rizik a redistribuce ztrát. Zájmy soukromého zisku stojí proti zájmům veřejného zdraví.

Charakteristikou rizikové společnosti je dialektika moderních byrokratických institucí, které reprodukují kolektivní hazardy a zároveň je usilovně administrují, přičemž ujištují veřejnost o své vlastní nezbytnosti a technické odborné způsobilosti při „ř́izení“ rizik (většinou však až poté, co dojde ke katastrofě a ohrožení je uskutečněno). Moderní instituce k tomuto rizikovému ř́zení využívají ekologické, environmentálně specializované vědecké a technické expertízy, jazyk ekologické kritiky proroctví apokalypsy a varovných předpovědí je integrován a „přeložen“ do jazyka institucionalizovaných systémů a reinterpretován ve smyslu legitimního důkazu o bdělosti a efektivnosti vlastního provozu institucionalizovaných systémů. Ve jménu manažerské pružnosti adaptivní organizace dochází ke kooptacím environmentální kritiky - přitom hlavní očekávání tzv. ekologické modernizace je spojováno s př́sliby diskurzivní vnitřní prèměny hlavních moderních institucí, např́iklad reformní změnou jejich hodnot či cílů, která má představovat výsledek „komunikativní racionalizace“ byrokratických systémů.

\section{Mocenská asymetrie a kontrola poznatků: vědění a byrokracie}

V reálných kontextech ovšem naděje, vkládané do komunikativní racionalizace byrokratických systémů (jak státních tak soukromých podnikových institucí) a do vnitřní přeměny institucí zevnitř, obvykle narážejí na konflikty expertíz mezi sebou a hlavně na častou deformaci komunikace jazykem technokratických expertíz. Aktéři nemluvící tímto jazykem jsou procedurálně diskvalifikováni a vyloučeni z dialogu i ze hry vyjednávání. Volání po obecných pravidlech procedurální rovnosti kontrastují často s deformací jazyka technokraticko-byrokratického kódování komunikace, anebo dialogy končí jako „rozhovory hluchého se slepým“. V byrokraticko-technokratických procedurách se mnohdy skrývá partikularizující zájem, který kontrastuje s veřejným zájmem. Aktéři občanských hnutí narážejí na kontrasty laiků a expertů i na byrokratické rozpory meritorních ofi- 
ciálních cílů a cílů skutečných. V administrativním procesu dochází k oddělování faktů a hodnot, problémem je často velmi úzká specializace expertů, fakta, o kterých experti diskutují, jsou vyňata či expertně vypreparována z širších hodnotových a kulturních kontextů, odborné diskuse se orientují na „čistě technická řešení “ atd.

Kritikové byrokraticko-technokratických empirických forem ekologické modernizace a kooptace environmentalní kritiky D. Torgerson a R. Paehlke ukázali například, že administrativní sféra obecně (tzn. soukromý byznys a státní správa) je historicky hlavním producentem ekologických problémů [Torgerson, Paehlke1994]. Jestliže je byrokracie hlavním organizátorem diskuse o jejich řešení, pak dochází k potlačení rozdílných pohledů a k vytvoření uzavřeného politického procesu omezujícího otevřenou demokratickou participaci. Dominantním motivem administrativní sféry je integrovat formulace kritiky skutečných problémů rizik a ohrožení jako zelené mimikry k legitimizaci vlastní činnosti.

Paehlke v této souvislosti zdůraznil potřebu zastoupení (representace) zájmů všech občanů, kterých se týkají rozhodnutí o životním prostředí. Splnění této podmínky je v praxi často blokováno formálními procedurami legislativy a celkovou formalizací komunikace a participace. Nedostatek informací způsobený tendencí byrokracie k utajování - naopak provokuje pochyby a protesty na straně laické veřejnosti. To ovšem ve výsledku ohrožuje samotné byrokracie, jež se dostávají do pozice normalizátorů rizik a ohrožení a organizované nezodpovědnosti, která legalizuje ohrožení a má stále rozsáhlejší dopady [Perrow 1981: 198; Beck 1988]. Proto je důležité veřejně komunikovat poznatky o tom, jak a kým jsou ve společnosti normativně vymezována rizika.

V praxi fungování institucí je udržována nerovnost - a to také znamená, že neexistuje stejná šance pro participaci při strategickém rozhodování. Na jedné straně stojí mocné organizace, transnacionální podniky vybavené zdroji kapitálu a technikami s globálním dosahem - na druhé stojí ti, kdo jsou vystaveni rizikům a dopadům rozhodnutí a jednání. Jednotlivci v populaci jsou vystaveni sociálně vytvářenému kolektivnímu ohrožování a nemohou se k riziku vyjádřit předem. Mocenská nerovnováha narůstá, pokud nedostatečně fungují regulativní mechanismy zavazující kolektivně všechny dotčené a zúčastněné aktéry ke spolupráci při rizikovém rozhodování ex ante a neexistují nebo nefungují instituce reprezentující obhajobu práva občanů na zdravé životní prostředí jako na veřejný statek.

\section{Ekologické vědění a politika kulturní změny}

Výzva ekologické krize moderní civilizace, utváření ekologického povědomí a konečně sociální percepce a akceptace nové povahy rizika občanskou společností, státem i kapitalistickým soukromým sektorem - to vše bylo posilováno konstrukcí environmentálního vědění a komunikací nových poznatků. Nositeli tohoto vědění a komunikace v novém diskurzivním prostoru veřejnosti v průmyslových společnostech globálního Severu a nyní též v zemích globálního Jihu byla především občanská hnutí protestu proti ohrožení životního prostředí. K největšímu rozmachu hnutí protestu došlo v období konce šedesátých a první poloviny let sedmdesátých dvacátého století. Protest náhle zpolitizoval dříve nepolitické otázky fyzického prostředí a vyzdvihl etické dilema společností ovládaných ekonomickým růstem, rozdělováním bohatství a masovou spotřebou. Mo- 
rální rozhořčení nad ohrožováním lidí, zvířat i rostlin bylo adresnou kritikou samozřejmého a nereflektovaného bezpráví každodenní rutiny fungování systémů industriální civilizace. Moralizace a politizace tzv. neutrální problematiky fyzického prostředí jako technické problematiky - např. konzervace přírody, úspory surovin nebo nápravy škod znečištění - posunula problém $\mathrm{z}$ „Vnějšku“ dovnitř, do společnosti - a vyvolala potřebu reflexe nejen ekologického komplexního prrístupu ke vztahům společnosti a př́rody, ale také nezbytnost reflexe fenoménu ekologické krize sociálně-vědními přístupy.

Takto např́iklad sociologie, jež původně ekologii chápala jako př́rodovědeckou oblast a jen částečně spojovala její některé aspekty s urbanismem a životem ve městech, přešla v pojetí některých autorů (např. K. Eder, U. Beck, A. Giddens ad.) k pojmu zespolečenštění prírody. Tento pojem znamená hledisko překonávající dualismus rozporu mezi přírodním a společenským. V globálních sítích kapitalismu je stále patrnější integrace přírodního světa do rámce civilizačních a politických rozhodovacích procesů. Zespolečenštění přírody je zprostředkováno intenzitou sociálního využívání poznatků vědy, vědeckým věděním, technickým využitím a přetvářením přírody a jejích sil v produkci, dopravě, v konstrukci komplexních sociotechnických systémů. Rostoucí význam pro rozvoj sebereflexe moderní společnosti má komunikace vědomí o vzájemné propojenosti a závislosti společnosti a př́rody, jež se projevuje nikoli jen závislostí společnosti na přírodě - nýbrž stejně tak narůstající závislostí obyvatelnosti pozemské prírody na společenských institucích. Environmentalismus jako hnutí protestu a kritické reflexe obecně nastolil novou diskurzivní formaci o politice životního prostředí jak v národních společnostech, tak i nadnárodně, v globálním prostoru.

\section{Integrace environmentálního hnutí a politická kultura}

Vzniká otázka, co se v soudobých společnostech mění vlivem environmentalismu a jak se jako hnutí mění sám environmentalismus. Byl nakonec environmentalismus úspěšný? A. Jamison chápe sociální hnutí jako fenomén spojující sociální konflikt a kulturní participaci, ekologické hnutí je podle něho hnutím kulturní změny. Hnutí je sociálním procesem, jenž chápe cyklicky jako střídání fází: růstu a expanze - stagnace a krize. Participace lidí je ovlivněna kontexty jednání, které autor nazývá „ideálními typy politické kultury“. Politický život definuje jako proces interakce v podobě konfliktu a spolupráce mezi představiteli politických kultur. Interakce jsou kulturním napětím tří typů politických kultur: státní-byrokratické, ekonomické-podnikatelské, občanské [Jamison 2001].

Jamison zkoumá vývoj ekologické diskuse od ochrany životního prostředí ke kulturním transformacím, kdy se problémy ochrany životního prostředí staly narůstajícím sektorem veřejné politiky a ekologický diskurs napomohl přijetí ekologického vědomí do národních kultur průmyslových společností. Obecnou ideou integrace ekologické péče do všech aspektů sociálního a ekonomického života se stala myšlenka udržitelného rozvoje. ${ }^{1}$

\footnotetext{
Jednat udržitelně znamená jednat s ohledem na budoucí generace. „Pro naši generaci může být bilance zdrojů ještě kladná, ale naše děti po nás zdědí už jen ztráty. Aniž hodláme tyto dluhy splácet, vypůjčujeme si ekologický kapitál od př́štích generací. Ty nás asi za naše marnotratné způsoby proklejí, nebot' nikdy nebudou moci získat zpět, co jim dlužíme. Jednáme tak proto, že si to můžeme dovolit: př́iští generace nevolí, nemají politickou ani finanční moc, nemohou napadnout naše rozhodnutí " [Světová komise pro životní prostředí a rozvoj 1991: 20].
} 
Nové slogany zelenání průmyslu a ekologické modernizace nahradily původní rétoriku limitů růstu. Bývalí aktivisté protestního hnutí pravidelně radí soukromému byznysu jak nejlépe vystupovat a demonstrovat svou ekologickou odpovědnost. Environmentalismus pronikl do konstruktivních programů technické, ekonomické a sociální inovace. Přístupy předběžné opatrnosti a preventivní principy vyloučení znečištění před jeho vznikem nahrazují řešení ex post. Narůstá uvědomění potřeby změn v celé společnosti. Mocenské pozice už neberou environmentalismus primárně jako nebezpečí pro další expanzi industriální společnosti. Ve vládě i v soukromém byznysu začínají mít vliv aktéři, kteří považují péči o životní prostředí za př́ležitost k podnikání a pozitivní faktor ekonomické obnovy a zisku, konstatuje Jamison obdobně jako M. Hajer, který hovoří o procesu tzv. ekologické modernizace.

\section{Proces ekologické modernizace}

M. Hajer vidí v procesu ekologické modernizace přímo nový typ environmentální politiky jakožto politiky kulturní. Jejím hlavním cílem má být integrace ekologického povědomí do existujících politických, ekonomických a sociálních institucí. Jde tu především o započítávání nákladů na ekologické poškození (internalizaci) na bázi cost-benefit analýzy. Ekologická péče je nyní manažerským problémem, jak sladit ekologickou péči a ekonomický růst v rámci tzv. udržitelného rozvoje. Nové pojetí environmentalismu nemá řešit věci ex post, nýbrž anticipativně rozhodovat ve smyslu prevence rizik. Namísto rozdělování detailních mikroproblémů v popisech dílčích disciplín a institucionalizovaných administrativních orgánů jde nyní o integrovaný př́stup všech rezortů vládní politiky. Také průmysl začal víc aplikovat princip předběžné opatrnosti ve své strategii. Stát i průmysl nyní údajně uznaly prrírodu jako veřejný statek a nikoli něco, co není ničí. Uznání rozsáhlého ekologického problému širokou akceptací ve společnosti implikuje podle teorie ekologické modernizace praxi širšího partnerství různých aktérü environmentální politiky, v níž narostla moc expertních organizací. Změnu vidí Hajer také $\mathrm{v}$ tom, že nejen stát regulačně omezuje podnikání, ale také byznys sám oceňuje ekologické dopady svého podnikání ve smyslu oceňování své vlastní neefektivnosti a bere ekologii jako výzvu $i$ šanci $k$ inovaci organizace, spotřeby, trhu, metod výroby, dopravy aj. Tak se mění smysl ekologické krize z hrozby systému v nástroj jeho inovace [Hajer 1988: 24-41].

Na druhé straně je však realitou, že s prohlubováním procesů globalizace se objevují stále nové formy exploatace zdrojů ve světě s tím, jak nadnárodní podniky usilují o přeměnu snah o udržitelný rozvoj v nové podnikání a v nové zisky. Zeleně pouze mluvící, ale de facto nejednající firmy (jedná se rovněž o velmi častý problém pragmaticky používaných dvojích měřítek v chování globálních korporací tzv. double standards podle země či regionu, kde působí) jsou oponovány různými opozičními protesty ve světě. A. Jamison konstatoval, že rostoucí ekologické uvědomění přestalo být zdrojem identity malých kolektivit aktivistů a odborníků a začalo již ovlivňovat celou společnost jako zdroj inspirace, ale zároveň i přes rozšířenou zelenou rétoriku pokračuje úpadek zdraví planety a jejích obyvatel v globálním měřítku [Jamison 2001: 18].

Při hodnocení sociálních procesů úsilí o udržitelný rozvoj soudí Jamison, že tyto procesy vedou ke kulturní a kognitivní transformaci soudobých společností v závislosti na 
kontextech politické kultury a usilují o přetvoření diskurzivní, institucionální i vědeckotechnické praxe.

Také M. Hajer ukazuje, že situace soudobých environmentálních konfliktů a debat o politických přístupech, organizačních iniciativách a reformách, má charakter symbolické „kulturní politiky“. Hajer rozlišil starou a novou kulturní politiku životního prostředí: první se vyznačuje důrazem na státní byrokratické instituce, legislativu a funkčně diferencovaný přístup rozkládání reality životního prostředí do malých oblastí (např. ovzduší, půda, voda).

Od poloviny 80. let se formuje nová politika ekologické modernizace, založená na prosazování akcentu na integrování péče o životní prostředí do většiny existujících, stávajících politických, ekonomických a sociálních institucí, hledá nástroje zakalkulování ekologických škod na základě analýzy nákladů-př́nosů (cost-benefit analysis). Principem ekologické modernizace je participace jedinců, organizací a států. Dalším principem a sloganem je udržitelný rozvoj jako pragmatický, utilitární most mezi ekonomickým růstem a ochranou životního prostředí. Ekologické škody jsou pak chápány nikoli jako brzda růstu, ale snahy o jejich nápravu jsou využívány jako nový podnět pro růst. Například znečištění se chápe jako důkaz neefektivnosti, výroba čistých technik a ekologických příznivých technických systémů bude stimulovat inovaci metod průmyslové výroby a distribuce, jinými slovy jde o Schumpeterovy „zásadní impulzy udržování kapitalistického motoru v chodu“ [Hajer 1996: 246-249].

Podle Hajera ekologická modernizace přinesla reálnou změnu myšlení o prrírodě a společnosti i změnu pojetí environmentálních problémů v kruzích vlád a průmyslu jako předpoklad strukturování diskurzu s novým étosem, podle kterého je prosté exploatování prírody bez ohledu na ekologické důsledky považováno za nelegitimní. Změnil se $\mathrm{v}$ tomto směru také charakter diskusí o technice a přírodě, nebo jde v podstatě o rozšíření stávajícího sociálního projektu modernizace určovaného primárně dynamikou vědy a techniky? Je tudíž dnešní „ekologická otázka“ následníkem „sociální otázky“, ptá se Hajer [1996: 250]. V soudobých společnostech se však empiricky rýsuje odpověd, v níž ekologický problém doprovází nárůst sociálních nerovností v posledních čtyřech dekádách konce dvacátého a počátku jednadvacátého století. Vzniká komplex vazeb mezi růstem chudoby a ekologickou devastací, mezi zvyšováním nákladů, růstem cen přírodních zdrojů a poklesem ekonomického i sociálního rozvoje.

\section{Diskurs ekologické modernizace, dilema kooptace a spor o politiku životního prostředí}

M. Hajer rozlišil několik diskurzivních linií myšlení o environmentálních problémech, přírodě, vědě a technice a společnosti. První z nich soudí, že ekologická modernizace umožňuje institucionální učení. Politický konflikt je procesem učení, v němž ekologické hnutí údajně „dozrává“ díky své institucionalizaci a jeho představitelé a zástupci jsou integrováni do systému, aby napomohli vytvoření nových institucionálních forem řešení ekologické krize. Z tohoto pojetí vyplývá v zásadě dosti optimistické přesvědčení reflexí ekologické modernizace a udržitelnosti rozvoje o tom, že kooptace environmentálního vědění, uvědomění, etiky odpovědnosti i kritiky environmentálních rizik 
umožňuje nové učení dominantních institucí, a o tom, že z tohoto procesu vyplyne jejich smysluplná změna.

Hlavním kritériem ekologické modernizace je integrování pojmu příroda do společnosti, nahrazení jejího zvnějšnění (externalizace) jejím integrováním a internalizací v podobě redefinice prírody jako subsystému společnosti a integrace ekologické racionality do sociálního rozhodování [Hajer 1996: 251-252]. Podle Hajera vede tato kulturní změna k přeměnám myšlení institucí státu a podniku ve smyslu „autopoietické sebeorganizace“, směrem ke koordinaci a centralizaci rozhodování. To vyžaduje také operacionalizovat jazyk, pojmy - tak, aby bylo možno rozhodovat o problémech kalkulačním způsobem v podobě oceňování ekologických hodnot v procesech rozvoje, hodnocení technických prostředků k zajištění ekologické kvality, změn ekologických kulturních vzorců lidského chování. Koordinace a centralizace jsou však, jak je dobře známo, tradičním rysem moderních byrokratických organizací (státy a posléze velké podniky) a ekologizace může být jen jednou z dalších oblastí, kterou se byrokracie pokoušejí administrovat. Přesněji řečeno, jde především o to, jak administrativně zvládnout „socializovanou př́rodu“ v podobě tzv. nezamýšlených důsledků technicko ekonomického využívání přírody. Ekologická modernizace je tedy $z$ tohoto hlediska expandováním byrokratizace a může být dobře využita pro opětovnou legitimizaci stávajícího systému jako nová eko-technokratická ideologie.

Rovněž zmíněná kalkulační redefinice př́rody jako subystému společnosti zároveň kvalifikuje ekologickou modernizaci jako technokratický projekt. Východiskem technokratického pojetí je konstatace, že technika se vymkla lidské kontrole, a že cíle politiky musí být stanoveny elitou odborníků, politiků a vědců, kteří definují problémy a řešení, o nichž se debatuje. Za rétorikou ekologické modernizace se rýsují obrysy technokracie v novém hávu „implementace reálných řešení reálných problémư“.

Antitechnokratická sociální kritika zdůrazňuje v této souvislosti, že ani stát, ani podnik se v podstatě od nových sociálních hnutí ochrany životního prostředí nic nenaučil, ale naopak jim v podstatě šlo o to, jak hnutí spíše potlačit, jak veřejně, tak „represivní tolerancí: „kritika pak zanikne v kooptování ekologického protestu do úředního legalistického diskurzu“ [Torgerson 1994].

V tomto ohledu tedy nejde o vyzrávání ekologického hnutí a nové učení mocenských institucí, nýbrž o ekologickou modernizaci jako represivní odpověd' na radikální ekologický diskurz, nikoli však jeho produkt. Jakmile je ekologická otázka uchopena mocenskými aparáty, stane se z ní další nástroj jejich ovládání každodennosti, zdůrazňují analytikové kritické politické ekologie [Gortz 2002: 57; Paterson 2001]. Tato sociální kritika technokracie je i kritikou pojetí „trvalé udržitelnosti“v koncepci Brundtlandové jako pojetí, které ignoruje vlivy sociálních rozporů a sociálních alternativ [Sachs 1993], kdy se zdá, že zelený globalismus chce pod sloganem „trvale udržitelného rozvoje“ (sustainable development) integrovat, pohltit všechny specifické lokální požadavky do globálně sdílené vize budoucnosti v zájmu globálního Severu, a přitom však obavy z další závislosti (tentokrát ekologicky udržitelné podle vědecko-manažerského scénáře) na straně globálního Jihu přiživují odpor vůči inkorporaci, usuzuje W. Sachs [1993: 158-161].

V podmínkách soudobé globalizace při prohloubení nerovností mezi globálním Severem a globálním Jihem jsou často požadavky technokratického globálního manažerismu na trvalou udržitelnost konfrontovány se sociálními problémy bídy a chudoby. Západní koncepce environmentalistických hnutí jako hnutí založených na vědě a vědění zpochyb- 
ňujících politiku rizika a jeho kalkulace v rámci institucí, které se snaží řídit nejistoty je konfrontována s globálními ekologickými hnutími Jihu, jež stále silněji odmítají globalizující a modernizační kulturní transformace ve jménu tradičních kulturních domorodých tradic (hnutí indigenizace) a mnohdy hájí zájmy rolnických skupin a přežití, obživu venkovské populace. V tomto zásadním protikladu Sever-Jih se obráží podstatný konflikt globalizační situace, jímž je nerovná redistribuce ekologických a sociálních rizik.

Experti environmentalismu ze Severu zde stojí proti každodennímu zakoušení rizik destrukce životního prostředí v rozvojových zemích. Proti globálnímu ekologickému manažerství stojí více lokální, místně orientované protesty hnutí domorodců proti sociálně ekologickému bezpráví. Globalizovaný environmentalismus podle některých analýz spoléhá více na experty „trrídy vědění“ a ignoruje sociální cíle lokální participace hnutí za environmentální spravedlnost (environmental justice). Podle R. Dwivendiho bude globální ekologická politika nucena respektovat dva reálné problémy. Prvním je zostrovování konfliktů Severu a Jihu o zdroje na lokální úrovni v důsledku globalizace trhu, druhým je zostření bojů při vyjednávání o péči o životní prostředí mezi tržními a politickými aktéry. Institucionalizace politiky environmentálních rizik by se měla strategicky reorientovat a odborné vědění by mělo více sloužit artikulaci širších zájmů a práv občanů ohrožovaných environmentální degradací ve všech lokalitách globálně propojeného světa. Odtud logicky vyplývá nezbytnost nového propojení při utvárení silné politické koalice mezi environmentalisty a dalšími občanskými sociálními hnutími za lidská a sociální práva, práva žen, etnických skupin a kultur. Příkladem je hnutí za environmentální spravedlnost, které spojilo ekologickou péči s lidskými a sociálními právy, participační demokracií sociálně ekologicky udržitelnějšího rozvoje [Dwivendi 2001: 26-28].

Dalším významným argumentem hodnocení pojmu ekologické modernizace je fakt, že ekologická krize je v sociálně kritické linii chápána jako především krize institucionální (v tomto smyslu je inspirována i koncepce „organizované neodpovědnosti“ U. Becka). Torgerson a Paehlke například hovoří o obtížnosti řídit Leviathana byrokratických institucí industriální civilizace - konstatuje se nemožnost poučení ze strany dominantních institucí [Torgerson, Paehlke 1994]. Tyto instituce nemohou řšit problémy, které samy způsobují svým výkonem a chováním i cílovým zaměřním. Jde o principy efektivity, technické inovace, o technovědní management, procedurální integraci a koordinační řízení. K jakým cílům a zájmům jsou tyto nástroje využívány? Lze věřit, že růst vyřeší důsledky růstu? Je udržitelný rozvoj dalším modelem shora, jenž místo slíbeného dobra přinese zlo? Problémem jsou samy cíle a nestabilita globálního kapitalismu s inovacemi založenými na výměnách zařízení a generací dělníků, a tak představují spíše strukturální limity ekologické modernizace. Planetu nespasí ekologický software, pokud obsahem hry zůstává kapitalistický expanzivismus, konstatuje rovněž jinak spíše optimisticky a konstruktivně naladěný M. Hajer [1996: 255].

Kritika technokracie ukazuje také roli věd $y \mathrm{v}$ kooptaci - jako vědy, která je ve své převažující většině inkorporována do tohoto technokratického projektu (např. systémová ekologie). Institucionální rámec přírodních a technických věd určuje rozvoj technik kontroly nad přírodou a společností a sociální vědy vytvářejí techniky sociálního inženýrství $\mathrm{k}$ dosahování předurčených politických cílů. Je třeba více rozvíjet alternativní kontraexpertízu, jak v přírodních vědách, tak ve vědách sociálních (nejde například o to, jak měnit individuální konzumní vzorce, ale o to, jak analyzovat imanentní síly civilizační 
apokalypsy). Sem patři také kritika hierarchie a centralizace požadující více demokratické kontroly a voleb v občanské společnost $i$ - v rovnováze k moci státu (referenda, právo na informace veřejnosti, decentralizace a samosprávné prvky aj.). Kritika ekologické modernizace jako technokratického projektu připomíná Habermasův koncept kolonizace životního světa systémem a Galtungův (dříve Heideggerův) pojem kolonizování budoucnosti.

A konečně, ekologická modernizace může být chápána také jako kulturní politika. V ní jde především o otázku, jakou společnost vlastně chceme? Pojem ekologické krize je chápán jako sociální vyprávění, diskurzivní konstrukce pojmenování problémů a hledání možností jejich řešení. Tyto směry vyprávění poskytují kognitivní mapy orientace sociálního jednání, přičemž se redukují a vynechávají některé aspekty skutečnosti a s jinými je manipulováno [Hajer 1996: 256]. V sociálně-vědní reflexi jde o odhalení způsobu, jakým jsou tyto konstrukce využívány a vytvářeny v interakcích diskurzu a takzvané diskurzivní koalice je třeba posuzovat $\mathrm{z}$ hlediska zájmů demokratické veřejnosti a sociálních sil stojících v pozadí ekologické modernizace.

Ideálním cílem ekologické modernizace v tomto smyslu je vytvoření alternativních možností, voleb a scénářu (budoucího) vývoje. Ekologické diskuse jsou zaměřeny hlavně na sociální vztahy prrírody, společnosti a techniky. Jaká představa o těchto vztazích převládá $\mathrm{v}$ různých dobách ekologické diskuse - jak se liší jejich kulturní významy v různých kontextech, do jaké míry jsou nevhodně globalizovány lokální definice (například obsah vymezený v podmínkách globálního Severu se aplikuje na globální Jih): to jsou otázky, o které jde př̌edevším v podmínkách současné globalizace světa. Přitom je z hlediska globální spravedlnosti politicky sporné, zda problémy způsobené hlavně Severem se mají řešit převážně v zemích Jihu. Pokud považujeme hnutí životního prostředí za hnutí založené na vědeckých poznatcích, které kritizují politiku rizika a přitom zpochybňují instituce, jež kalkulují rizika a ř́dí nejistotu, pak jde o kognitivní zápas, který nelze oddělovat od občanské společnosti a od konfliktnich sociálních zájmů a nerovností. V podmínkách globálního Jihu se toto hnutí konfrontuje nebo spojuje se specifickými cíli tzv. indigenizace, tzn. s hnutími na obranu původních kultur. Tato konfrontace je v praxi často rozporem myšlení a jednání lidí $z$ oblasti vědecké expertízy a lidí, kteří na své kủži zakoušejí poškození životního prostředí a nerovnou distribuci ekologických rizik, která se spojuje s dalšími úrovněmi sociální nerovnosti. Pokud se environmentalismus bude opírat pouze a především o experty z globálního Severu bez ohledu na zájmy přežití lidí Jihu, nebude riziková politika environmentálních hnutí ušetřena „nezamýšlených důsledkü“ $v$ podobě komunikační bariéry lokální spolupráce a participace mezi globalisty Severu a lokálními cíli inspirovanými hnutími Jihu [Dwivendi 2001: 27]. V důsledku procesů globalizace ekonomiky a trhu dochází ke konfliktům o zdroje především na lokální úrovni, pro ekologické hnutí se stane hlavním problémem právo místních obyvatel na vodu, půdu, lesy, obydlí. Zostření těchto sporů by mělo vést k vyjednávání mezi politickými i tržními aktéry a k adaptaci na normy péče o životní prostředí (včetně udržitelnosti ekosystémové i sociální), akumulované expertní vědění by mělo lépe sloužit zájmům a právům širší občanské veřejnosti. Environmentalistické skupiny by měly ve větší míře než dosud globálně i lokálně spolupracovat s občanskými hnutími za práva etnických skupin, žen, či lokálních kultur. Vzorem by zde mohlo být hnutí za ekologickou spravedlnost, spojující péči o životní prostředí s lidskými právy a demokratizací udržitelného rozvoje [Dwivendi 2001: 28]. 
Uvedené souvislosti ukazují proto, že není možné univerzalisticky a globálně vycházet z jedné objektivní pravdy - sociální konstruktivismus veřejné diskuse o environmentálních a technologických rizicích je antiobjektivistický, samotné vědecké konstrukce nemohou být jediným východiskem politiky (vědní paradigmata jsou časově a historicky podmíněna a jsou tedy relativní), jde tudíž o konstrukce omezené kulturními významy, zkušeností, politicko-ekonomickými strukturami - každá teorie i vědecký mýtus konečně vyjadřuje politické zájmy, kulturní metafory, osobní interakce a profesionální zájmy vyjednávané $\mathrm{v}$ zápase o definici, pojmenování světa. Ekologická krize tedy může být chápána jako především diskurzivní realita vytvořená sociálními procesy [Hajer 1996: 258].

$\mathrm{V}$ tomto smyslu je třeba konfrontovat jazyk vědy a expertů s jazykem laiků jako dvou rovnocenných způsobů diskutování o ekologických problémech, na cestě $\mathrm{k}$ hlubšímu pochopení a více demokratickému a veřejnému vyjednávání variant, které si společnost zvolí. V diskusi již nemusí jít hlavně o ochranu životního prostředí, ale spíše o to, jakou společnost a př́rodu chceme. Nemusí jít o pojetí techniky jako imanentního problému, ale také o techniku jako sílu umožňující přeměnu sociálních vztahů mezi přírodou, technikou a společností podle různých cílů a potřeb. Diskuse o životním prostředí pak ztrácí svůj zjednodušující rozměr sporů modernismu a antimodernismu, přičemž výsledkem může být diskuse o obnově společnosti. Pak je cílem diskurzu spíše otázka, jaké techniky zvolit a jak je koncipovat - i otázka, jak vhodně zespolečenštovat př́rodu, nikoli ji pouze chránit [Hajer 1996: 260]. A v tomto smyslu také jde o demokratickou diskusi za účasti širší občanské společnosti o tom, jak legitimizovat a organizovat určité zásahy v životním prostředí lokálně i globálně (s uvážením jejich důsledků). V této souvislosti je významná třebas otázka celospolečenského průzkumu, jež opravňuje občany $\mathrm{k}$ vlastní iniciativě požadovat změny určité politiky. Přitom jde nikoli o prosazování jednoho úzce definovaného úkolu, ale o hledání rozporů, zjednodušení složitosti a o diskusi o pochopení techniky, prrírody a společnosti a budoucích scénářủ jejich vývoje a jejich vzájemného působení. Významným cílem diskuse by mělo být také posouzení, jakým způsobem se dochází $\mathrm{k}$ novým náhledům na společnost a přitom zkoumat, jaké nezamýšlené potenciály mají určité technologie a jejich aplikace při utváření nových identit. Celkově je př́stup kulturní politiky zaměřen k nalézání smyslu soudobé ekologizace rizik modernizace.

Hajer ovšem také přiznává, že ve skutečné dynamice ekologické modernizace dochází - při byrokratických institucionalizacích a inkorporacích kooptujících kritiku environmentálních důsledků modernizace - $\mathrm{k}$ „racionalizaci ekologie“, jejíž „sociální efekty jsou v rozporu s původními úmysly environmentálního hnutí [Hajer 1996: 261]. Jde tudíž velmi aktuálně o obsah, smysl a cíle ekologické modernizace jako širší možnosti kritické kulturní politiky a o reflexi smyslu a důsledků ekologické krize.

Hajer uvádí kupř́íkladu tendenci $\mathrm{k}$ dalšímu ztechnizování ekologie - v rozvinutých průmyslových zemích i ve strategických plánech velkých nadnárodních firem, $\mathrm{v}$ řadách nevládních organizací jako je Greenpeace. Hlavní cíle se týkají eko-industriálních inovací a zájmové koalice dále podporují spojení ekologických problémů s novým nadšením pro technický rozvoj. Také nevládní organizace podporují technické projekty podmořských tunelů, zmrazování ohrožených živočišných druhů. Diskuse o ekologických otázkách biotechnologie vede $\mathrm{k}$ obhajobě techniky, která prý nespotřebovává př́iliš zdrojů. Hajer přiznává, že tato technizace ekologie není motivována ekologickým zlepšením, ale je to 
přeložení sociální a morální problematiky do sféry tržní: a tu se jedná o víru, o interes, podle nichž se jeví ekologizace jako potenciálně nový obrovský trh [Hajer 1996: 264].

Součástí sociální dynamiky ekologické modernizace je také ekologizace sociálního jde tu o problém praxe, založené na přesvědčení o řešení problémů pomocí integrace ekologie do stávajících sociálních systémů. Často zde působí sociálně demokratická víra v modernismus a produktivismus. Praxe pak vypadá tak, že „ekologické“, jako „eko-dimenze“ či „kapitola“, je prriřazováno - jako pouhý přivěsek, přístavek nejen národních, ale také nadnárodních nebo mezinárodních organizací. Proti tomu se rozvíjí nový regionalismus a lokalismus, jako tzv. ideologie místa, které jsou někdy podporovány, utvářeny či využívány pravicovými nacionalistickými silami boje „proti globalismu“ (pod heslem „místo proti prostoru“), proti imigraci, jež domněle povede k růstu populace a devastace národního životního prostředí atd.

Konečně, velký politický a etický význam má také tendence socializovat ekologii - tj. spojit diskusi o problémech životního prostředí s diskusí o odpovědnosti, demokracii, sociální spravedlnosti, o roli techniky ve společnosti a o změnách společnosti a existujícího sociálního uspořádání (včetně globálního). Právě tento směr by mohl být příslibem budoucí změny celé povahy environmentálního diskurzu a vytvořit tak nový, mnohem komplexnèjší rámec ekologické modernizace, presahující fluktuace zájmových koalic a kooptací sledujících bludný kruh zachování relativní inertnosti stávajících struktur a institucí i celého systému.

\section{Závěr: dilema ekologické politické kultury - mezi kooptováním a reakcí}

Výsledkem procesu začlenění a kooptace protestního environmentalismu je podle dosavadních analýz rozporný proces vznikání ekologické kultury, působící v politické i ekonomické oblasti. Podle Jamisona musí vznikající ekologická kultura bojovat na dvou frontách - proti bohatým a mocným, kteří se snaží nové myšlenky zkomercializovat pro své obchodní cíle - a proti silám odporu zdola, jež mají své dílčí a odlišné cíle a potřeby (např.domorodá hnutí). Tak nastává dilema mezi kooptací a reakcí. Jamison podporuje pluralistické a komparativní pojetí technologického rozvoje namísto univerzalistického technokratismu, jako pojetí, jež respektuje specifiky př́spěvku různých kultur ke globálnímu formování vědy a techniky ve vzájemných interakcích. Vědeckotechnický rozvoj je pak nikoli lineární difúzí anebo technickým transferem - ale je to technologický dialog civilizací, technická změna je multikulturním hnutím idejí a zkušeností, dochází k vzájemnému prolínání nadnárodních a národních kontextů. Pod povrchem sociálních interakcí je ovšem nutno vidět různé a rozporné kognitivní praxe a sociální zájmy, včetně působení hlubinných hodnot, mýtů a předsudků, jež formují epistémé záměrů jednajících lidí. Analýzy a vytvářené vědění jsou pak v podstatě nikoli neutrální, ale zaměřené a angažované politické intervence v diskurzivních prostorech [Jamison 2001: 37-38].

Jamison proto dilema environmentalismu jako nové (politické) kultury chápe jako proces „zpětného ovládnutí alternativní kultury reziduální formací kultury hegemonní - v tomto smyslu se environmentalismus rozložil a byl inkorporován do konstruktivních programů technické ekonomické i sociální inovace. Součástí této inkorporace je i rozpor rétoriky udržitelného rozvoje a skutečné praxe jednání. Inkorporace a kooptace 
environmentalistických myšlenek a osob do vládních i podnikových struktur si vyžádala vytvoření nových administrativních a manažerských procedur, ale v praxi vzniká celá řada rozporů. Přes rétoriku udržitelnosti ve skutečnosti mnoho západních firem globálního Severu přesouvá např. odpady na globální Jih a pro země Jihu a jejich průmyslový rozvoj to znamená omezení udržitelného rozvoje: tzv. zelenání Severu vede k destrukci životního prostředí na Jihu, a tak dochází k dalšímu prohloubení globální nerovnosti. V politice životního prostředí reálně nefiguruje jedna expertíza, ale mnoho expertíz s pluralitou zájmů, jež ovlivňují vědění - vznikají soutěže vědění a jejich rozpory. Takto lze kupříkladu rozlišovat vědění akademické obce a expertízy komerčních konzultací, jež nejsou kontrolovány akademickými pravidly, nebo rozpor plánovacích strategií zelené produkce a nových forem občanské vědy (tzv. citizen science).

Kooptace systémem ovšem především způsobuje redefinováni samotného hnutí: růst sociálního vlivu jde ruku v ruce s profesionalizací a technokratizací environmentalismu, se změnami v obsahu sdělení v sociální komunikaci, spolu s jejich fragmentací a diferenciací. Diference radikál - reformista vytváří diferencující osu marginalizace - kooptace, občan, laik - profesionál, expert. Takováto klasifikace ovšem podle mého názoru ignoruje anebo stírá složitější skutečnost - a to, že expert či profesionál je zároveň občanem a mimo svoji specializaci také laikem. Jamison dále hovoří o „dialektice environmentalismu“ mezi fundamentalismem a realismem, s tím, že čím více lidí je vtaženo kulturním působením do environmentalistického úsilí, tím více je rozdroben veřejný prostor, protože působí mnoho různých zájmů, kontextů a životních praxí, jež vstupují do environmentální politiky. To autor ukazuje např́klad na kulturách byznysu a radikálního aktivismu. $\mathrm{V}$ politické kultuře byznysu je hlavním cílem zájem o zisk a prostředkem je zakomponování ekologického vědomí odpovědnosti do marketingové strategie. Tento cíl profitu a prežití v soutěži je také hlavním limitem zeleného byznysu. Kooptace či začlenění elementů ekologického hnutí do politické kultury existujícího institucionálního systému se projevuje také na nevládních organizacích v jejich stoupající byrokratizaci, připomínající spíše podniky, firmy byznysu, než hnutí [Jamison 2001: 145].

V kultuře radikálního aktivismu se projevuje velká diverzita a snaha upoutat na sebe pozornost veřejnosti a tím též médií. Podle Jamisona je používán nejasný pojem „zelené veřejné sféry" ve smyslu existence či neexistence prostoru pro nesouhlasná stanoviska ze strany kritické ekologie vůči společné agendě. Prostory pro souhlas a nesouhlas jsou tedy významnými atributy kultury a politiky diskurzu, přestože se podle Jamisona může zdát, že některé formy protestu proti globalizaci jsou spíše neproduktivní, přičemž ekologické argumenty jsou v jeho rámci podle Jamisona marginalizovány. Podle mého názoru jsou v tomto kontextu tyto argumenty spíše subsumovány pod širší cíle vznikající globální kontextualizací reformulovaných sociálních a lidských práv. Také dnešní ideologie hlubinné ekologie (z níž se prý vytratil původní filosofický obsah i apel „ekosofie“ Arne Naesse) využívaná radikálně extremistickým protestem, je podle Jamisona spíše medvědí službou dalšího prosazování zelené kultury a politiky [Jamison 2001: 149]. Nejsou však takovéto „fundamentalizující" protesty právě „reakcí na antiekologické reakce“, tj. reakcí, jež odmítá systémy kooptace v procesech mocenského využívání pojmů udržitelného rozvoje a ekologické modernizace, v nichž dochází k umlčení kritiky prosazování dílčích, privátních zájmů na hazardním managementu zisku, jenž se neohlíží na obyvatele planety? 
Také D. Torgerson se obává, že př́lišný nebo přehnaně nekompromisní fundamentalismus ekologické resistence může zlikvidovat praktickou hodnotu politického aktivismu v demokratické občanské participaci a oslabit možnosti získat nějaké pozitivní výsledky v politice [Torgerson 1994: 168]. A. Jamison pak výslovně varuje před záměnou „inovativní mobilizace tradic“ za „reakční fundamentalismus tradicionalistické víry“. Je možno souhlasit s Jamisonem, že jak ideologický fundamentalismus radikální zelené víry, tak i kooptační redukce „ekologické modernizace“ na zelený byznys a marketingovou reklamní komercializaci jsou deformacemi reálné praxe environmentální politiky [Jamison 2001: 179].

Na závěr zbývá dodat, že tato reálná praxe mocenského fungování institucí zatím málo přihlíží $\mathrm{k}$ důslednému propojení s otázkami, jež vznikají ve sférách veřejnosti a občanské společnosti, to znamená s otázkami odpovědnosti, demokracie, spravedlnosti, sociální role techniky a systémové změny společnosti, nejen v rámci národně státním, ale rovněž v rámci globálním. A právě to umožňuje rozkvět uvedených deformací v procesech kooptace. Environmentalismus, jenž vznikl jako hnutí s odlišným charakterem, než měla moderní sociální hnutí, a ve kterém nešlo explicitně o moc ve státě ani o redistribuci bohatství, ale spiše o hlubší kulturní proměny v systémových vztazích moderní společnosti k přírodě prošel ve svém sociálním a politickém kontextu výraznou proměnou. Cesta od kognitivní mobilizace a participace $\mathrm{k}$ institucionalizaci a kooptaci přinesla jak pozitivní formy diskurzivní participace a demokratizace občanské účasti, tak i problémy spojené s deformacemi kooptovaných cílů idejí, poznatků a informací institucionálními systémy - nejen států, ale př̀edevším organizací byznysu a medií. Přesto však nelze nevidět, že sociální spor o životní prostředí je součástí nekončícího procesu rozšiřování politického procesu, aktivizace občanské společnosti a kulturní politiky v odlišných, diferencovaných a sociálně i mocensky nerovných kontextech soudobého světa. $V$ politice životního prostředí se projevují rozpory expertokracie a demokracie, antiekologické reakce zájmových koalic i institucionálních struktur konfrontují fundamentální ekologickou kritiku. Politika udržitelného rozvoje a ekologické modernizace nejsou v reálných kontextech dnešního globálně propojeného a zároveň nerovně strukturovaného světa zdaleka tak univerzálními recepty na společenské transformace, jak by se mohlo zdát v normativní, teoretické či technokraticky chápané rovině.

\section{LITERATURA}

Alexander, Jeffrey. 2001 „Robust Utopias and Civil Repairs.“ International Sociology 16 (4): 321-334.

Beck, Ulrich. 1986. Risikogesellschaft. Auf dem Veg in eine andere Moderne. Frankfurt a. M.: Suhrkamp. (české vyd. 2004 Praha: Sociologické nakladatelství).

Beck, Ulrich. 1993. Die Erfindung des Politischen. Frankfurt a. M.: Suhrkamp.

Beck, Ulrich. 1988. Gegengifte. Die organisierte Unverantwotlichkeit. Frankfurt a. M.: Suhrkamp.

Dwivendi, Raini. 2001. „Environmental Movement in the Global South.“ International Sociology 16 (1): $26-38$

Gorz, André. 1994 „Political Ecology: Expertocracy versus Self-Limitation.“ New Left Review 202: 21-35.

Hajer, Marten. 1998. The Politics of Ecological Modernization. London: Sage.

Hajer, Marten. 1996. „Ecological Modernization as Cultural Politics.“ Pp. 246-256 in Scott Lash, Bronislav Szerzynski, Bryan Wynne (eds). Risk, Environment, and Modernity. London: Sage.

Mol, Andrea, Daniel Sonnenfield (eds.). 2000. Ecological Modernization Around the World: Perspectives and Critical Debates. London: F. Cass. 
Nash, Kate. 2000. Contemporary Political Sociology. Globalization, Politics, and Power. Oxford: Blackwell. Jamison, Andrew. 2001. Making of Green Knowledge. Environmental Politics and Cultural Transformation. Cambridge: Cambridge UP.

Paterson, Mathew. 2000. Understanding Global Environmental Politics. Basingstoke: Macmillan.

Perrow, Charles. 1982. Normal Accidents, Normal Catastrophes. Living with High Risk Technologies. New York: Basic Books.

Sachs, Wolfgang (ed.). 1993. Global Ecology: A New Arena of Political Conflict. London: Zed Books.

Světová komise pro životní prostředí a rozvoj. 1991. Naše společná budoucnost. Praha: Academia - MŽP ČR.

Torgerson, Doughlas. 1994. „Limits of the Administrative Mind: The Problem of Defining Environmental Problems." Pp. 136-170 in Doughlas Torgerson, Robert Paehlke (eds.). Managing Leviathan. London: Belhaven.

Torgerson, Doughlas, Robert Paehlke (eds.). 1994. Managing Leviathan. London: Belhaven.

Touraine, Alain. 1981. The Voice and the Eye: An Analysis of Social Movements. Cambridge: Polity.

Wallerstein, Imanuel. 2000. „Globalization or the Age of Transition?" International Sociology 15 (2): 262-279.

Weber, Max. 2001. Sociologie náboženství. Praha: Oikumene.

\section{SUMMARY}

This study article critically applies the Weberian mechanism of the routinization of charisma onto contemporary processes in developed states and global capitalist network relationships classified by some analysts as ecological modernization.

We should ask what means the systemic integration and co-optation of environmentalist critical challenge to the modern civilization: what is the result of "ecological modernization" - is it innovation and the systemic change, or is it rather new integration and system stabilisation? Co-optation of originally radical critique is exemplified in a framework of institutionalization of environmental discourse as formalised system of bureaucratic rules and technocratic expertise and procedures. The contemporary crisis of the interactions between human society and nature confronts the static image of the bureaucratic administration of the risks as something external and technically manageable. 